\title{
Preparation and characterization of an iron oxide-hydroxyapatite nanocomposite for potential bone cancer therapy
}

This article was published in the following Dove Press journal:

International Journal of Nanomedicine

I October 2015

Number of times this article has been viewed

\section{Murugesan Sneha \\ Nachiappan \\ Meenakshi Sundaram \\ Department of Biomedical Engineering, PSG College of Technology, Tamil Nadu, India}

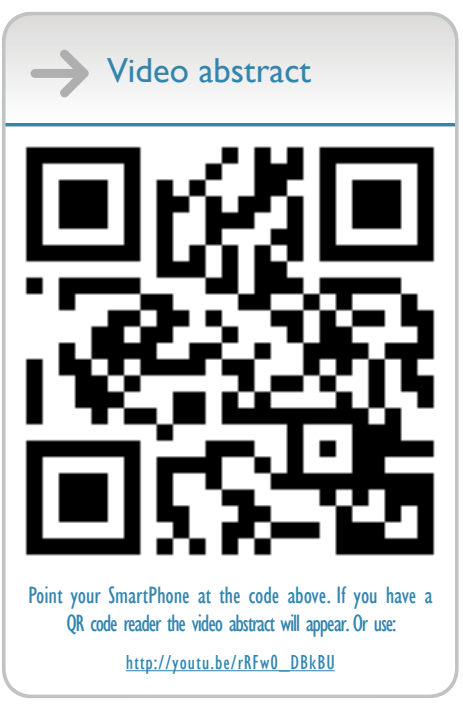

Correspondence: Nachiappan Meenakshi Sundaram

Department of Biomedical Engineering,

PSG College of Technology,

Coimbatore-04, Tamil Nadu, India

Tel +9l 4222572177

Emailnms@bme.psgtech.ac.in

\begin{abstract}
Recently, multifunctional magnetic nanostructures have been found to have potential applications in biomedical and tissue engineering. Iron oxide nanoparticles are biocompatible and have distinctive magnetic properties that allow their use in vivo for drug delivery and hyperthermia, and as $T_{2}$ contrast agents for magnetic resonance imaging. Hydroxyapatite is used frequently due to its well-known biocompatibility, bioactivity, and lack of toxicity, so a combination of iron oxide and hydroxyapatite materials could be useful because hydroxyapatite has better bone-bonding ability. In this study, we prepared nanocomposites of iron oxide and hydroxyapatite and analyzed their physicochemical properties. The results suggest that these composites have superparamagnetic as well as biocompatible properties. This type of material architecture would be well suited for bone cancer therapy and other biomedical applications.
\end{abstract}

Keywords: iron oxide, hydroxyapatite, nanocomposite, superparamagnetic, bone cancer

\section{Introduction}

Cancer is the most dreaded disease, along with heart disease. Hyperthermia has attracted much interest in the treatment of cancer due to its advantages over chemotherapy and radiotherapy. Using hyperthermia, cancer cells are killed directly within a short period of time, whereas normal cells are unaffected. ${ }^{1}$ Magnetic hyperthermia is practiced by applying an external alternating magnetic field which in turn oscillates the magnetic moment of each particle, converting magnetic energy into heat. Superparamagnetic materials for magnetic hyperthermia are promising candidates for antitumor therapy because they have the capacity to destroy deep tumors and are controlled by an external magnetic field. ${ }^{2}$ Magnetic nanoparticles have attractive features that could be used effectively in nanomedicine. First, they have a controllable particle size (from a few nanometers to tens of nanometers). Second, they are magnetic, so can be manipulated by an external magnetic field. Third, they can be made to heat up, so can be used as hyperthermia agents, delivering large amounts of thermal energy to tumor cells and destroying them. ${ }^{3}$ If an iron oxide nanoparticle is below $45 \mathrm{~nm}$ in size, it is classified as superparamagnetic due to its line-type hysteresis loop iron oxide nanoparticles. The magnetite $\left(\mathrm{Fe}_{3} \mathrm{O}_{4}\right)$ phase of superparamagnetic iron oxide nanoparticles has numerous in vivo applications, since it can respond to an external stimulus and heat up, and does not retain any magnetism after removal of the external magnetic field. ${ }^{4,5}$ Materials that are compatible with bone tissue are preferred for bone repair and hard tissue engineering. ${ }^{6}$ Hydroxyapatite (HAp) is widely used in this setting because of its exceptional biocompatibility, bioactivity, and osteoconductivity. ${ }^{7}$ A number of submit your manuscript $\mid$ www.dovepress.com

Dovepress

http://dx.doi.org/10.2147/IJN.S79985
International Journal of Nanomedicine 2015: 10 (Suppl I: Challenges in biomaterials research) 99-106 99 (c) (i) (5) 2015 Sneha and Sundaram. This work is published by Dove Medical Press Limited, and licensed under Creative Commons Attribution - Non Commercial (unported, v3.0) License. The full terms of the License are available at http://creativecommons.org/licenses/by-nc/3.0/. Non-commercial uses of the work are permitted without any further permission from Done Medical Press Limited, provided the work is properly attributed. Pents how to request permission may be found at: http://www.dovepress.com/permissions.php 
researchers have developed a variety of HAp-based magnetic materials for hyperthermia-based treatment of cancer. ${ }^{8-11}$

Murakami et al prepared a porous $\mathrm{Fe}_{3} \mathrm{O}_{4}-\mathrm{HAp}$ composite using a hydrothermal method. The composite holds $30 \%$ $\mathrm{Fe}_{3} \mathrm{O}_{4}$ in cages of rod-shaped HAp particles. ${ }^{8} \mathrm{Fe}_{3} \mathrm{O}_{4}$ nanoparticles are prepared by a coprecipitation method, and a horizontal tumbling ball mill is used to mechanochemically synthesize submicron-sized HAp particles. According to Iwasaki et $\mathrm{al}^{9}$ this process promotes the dispersion of $\mathrm{Fe}_{3} \mathrm{O}_{4}$ nanoparticles in the HAp matrix. The magnetic $\mathrm{Fe}_{3} \mathrm{O}_{4}$ particles are coated with HAp by spray-drying. Donadel et al found that the spray-drying technique is an efficient and inexpensive method for creating spherical particles with a core/shell structure. ${ }^{10}$ Tampieri et al prepared iron-doped HAp endowed with superparamagnetic properties for hyperthermic application. ${ }^{11}$

These composites can be synthesized conventionally by mixing HAp nanopowder with $\mathrm{Fe}_{3} \mathrm{O}_{4}$ nanoparticles that are prepared separately. In this work, $\mathrm{Fe}_{3} \mathrm{O}_{4}$ nanoparticles were prepared by alkaline coprecipitation of ferric and ferrous chloride in aqueous solution. Nanocrystalline HAp was prepared using an optimized sol-gel method. Dry (zirconia ball) milling was used to blend the $\mathrm{Fe}_{3} \mathrm{O}_{4}-\mathrm{HAp}(0.70 \mathrm{w} / \mathrm{w})$ nanoparticles. The $\mathrm{Fe}_{3} \mathrm{O}_{4}$-HAp nanoparticles and their composite were analyzed by Fourier transform infrared spectroscopy, diffuse reflectance spectroscopy, scanning electron microscopy, thermogravimetric analysis, differential scanning calorimetry, vibrating sample magnetometry, and cytotoxicity tests. The method proposed in this paper is easy and cost-effective for preparing these nanocomposites. The synthesis and characterization of this biocompatible magnetic biomaterial is explained in detail, and the nanostructured $\mathrm{Fe}_{3} \mathrm{O}_{4}$ - $\mathrm{HAp}$ composite is ideal for bone cancer therapy.

\section{Materials and methods}

\section{Synthesis of iron oxide nanoparticles}

$\mathrm{Fe}_{3} \mathrm{O}_{4}$ magnetic nanoparticles were synthesized by the alkaline coprecipitation method. The molar ratio of $\mathrm{Fe}^{3+}: \mathrm{Fe}^{2+}$ chloride was maintained at $2: 1$. The prepared magnetite was black in color and the $\mathrm{pH}$ was maintained between 9 and $14 .{ }^{12}$ The overall reaction is written as:

$$
\mathrm{Fe}^{2+}+2 \mathrm{Fe}^{3+}+8 \mathrm{OH}^{-} \rightarrow \mathrm{Fe}_{3} \mathrm{O}_{4}+4 \mathrm{H}_{2} \mathrm{O}
$$

\section{Synthesis of HAp nanoparticles}

The HAp nanoparticles were prepared by the wet chemical route method. First, $0.25 \mathrm{M}$ phosphoric acid was prepared in distilled water. Ammonia $\left(\mathrm{NH}_{3}\right)$ was added to this solution, with stirring to maintain the $\mathrm{pH}$ at 10 . Next, a $1 \mathrm{M}$ calcium nitrate tetrahydrate solution was prepared by dissolving in double-distilled water, which was then added slowly to the above phosphoric acid-ammonia solution. The solution was stirred vigorously for 1 hour and allowed to age at room temperature for 24 hours. The gel obtained after aging was dried at $80^{\circ} \mathrm{C}$ for 48 hours in a dry oven. The resulting mixture were washed repeatedly using distilled water. After washing, the powder was sintered for 2 hours at a temperature of $900^{\circ} \mathrm{C}$.

\section{Synthesis of $\mathrm{Fe}_{3} \mathrm{O}_{4}-\mathrm{HAp}$ nanocomposites}

The $\mathrm{Fe}_{3} \mathrm{O}_{4}$-HAp nanocomposites were prepared using a wet-type ball mill (Figure 1A). The ratio of $\mathrm{HAp}$ to $\mathrm{Fe}_{3} \mathrm{O}_{4}$ nanoparticles was 1.5:1 (w/w). Ball milling was carried out for 5 hours using a zirconia bowl and ball at $300 \mathrm{rpm}$, with a ball to sample powder ratio of 10:1 (w/w).

\section{Characterization}

Fourier transform infrared spectra were taken using an 8400S spectrophotometer (Shimadzu, Tokyo, Japan). $\mathrm{KBr}$ pellets were used, and the spectra were recorded in aqueous medium.

The morphology of the $\mathrm{Fe}_{3} \mathrm{O}_{4}$-HAp nanostructures was observed using a scanning electron microscope (ICON, Quanta 200 Mark II Environmental scanning electron microscope) with an acceleration voltage of $0.2-30 \mathrm{kV}$.

The thermal properties of the prepared nanocomposites were investigated using a thermal analyzer (STA 449 F3 Jupiter, Netzsch Gerätebau GmbH, Selb, Germany) along with thermogravimetry and differential scanning calorimetry in the temperature range of $28^{\circ} \mathrm{C}-1,100^{\circ} \mathrm{C}$ at a heating rate of $20^{\circ} \mathrm{C}$ per minute in a dry air atmosphere. $\mathrm{Al}_{2} \mathrm{O}_{3}$ was used as the reference material.

Diffuse reflectance spectroscopy was performed using a Specord 210 Plus (Analytik Jena, The Woodlands, TX, USA) between 190 and 1,100 $\mathrm{nm}$ at room temperature.

The superparamagnetic properties of the $\mathrm{Fe}_{3} \mathrm{O}_{4}-\mathrm{HAp}$ nanocomposites were studied using a 7410 vibrating sample magnetometer (Lake Shore, Westerville, OH, USA), in atmospheric air at room temperature.

The cytotoxic effects of the $\mathrm{Fe}_{3} \mathrm{O}_{4}$-HAp nanocomposites were evaluated using MG63 cells. The MTT assay was performed according to the procedure shown in Figure 2. The formazan was dissolved in dimethyl sulfoxide and the absorbance of the solution was quantified at $510 \mathrm{~nm}$. 


\section{A}

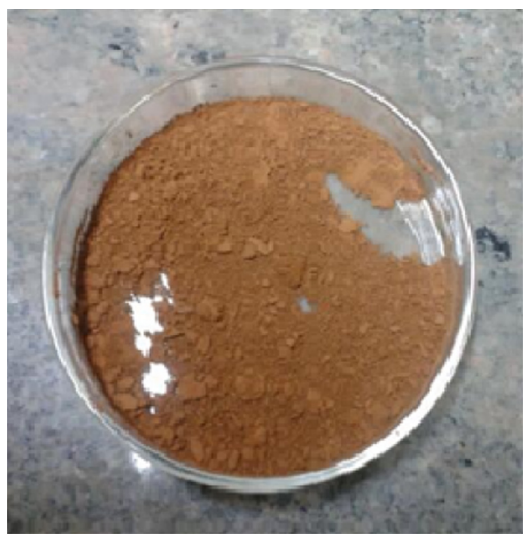

C

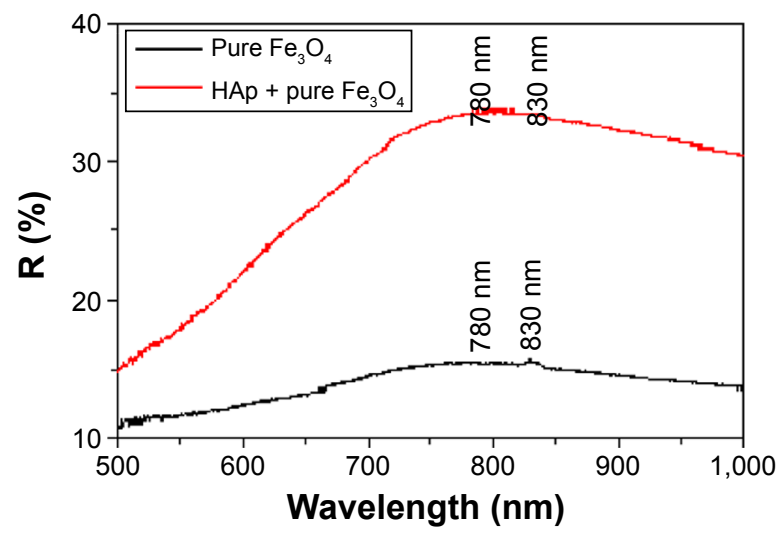

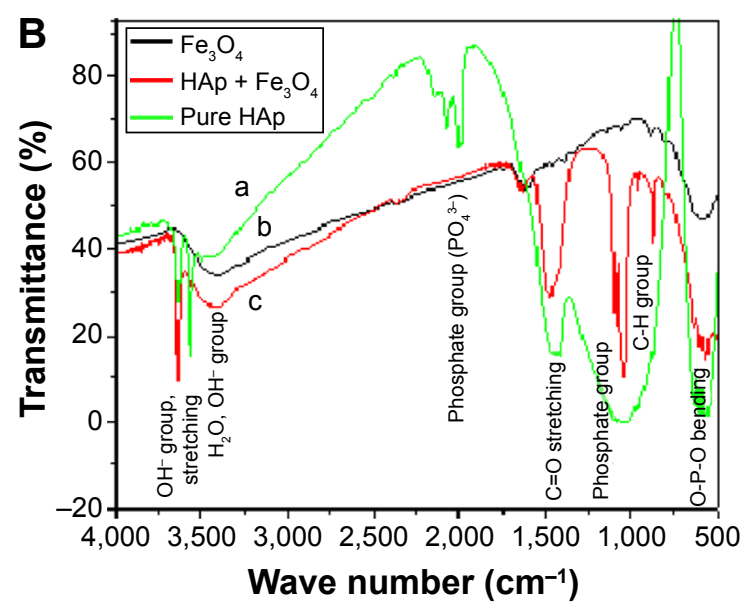

D

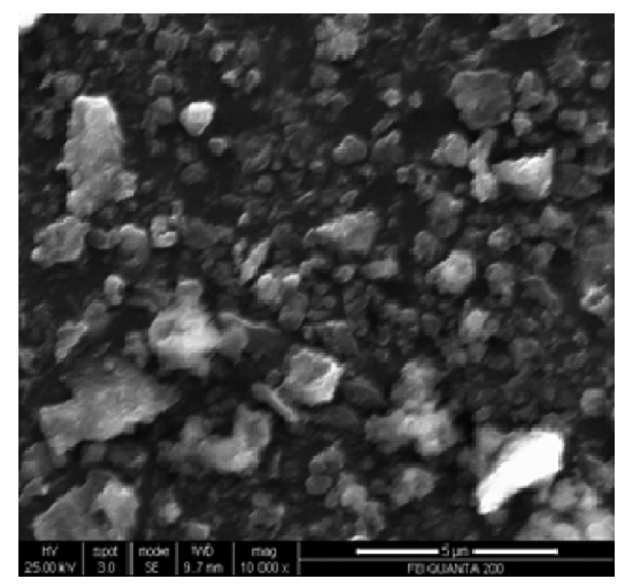

Figure I (A) $\mathrm{Fe}_{3} \mathrm{O}_{4}-\mathrm{HAp}$ nanoparticles in powder form. (B) Fourier transform infrared spectra of $\mathrm{HAp}_{3}, \mathrm{Fe}_{3} \mathrm{O}_{4}$, and $\mathrm{Fe}_{3} \mathrm{O}_{4}-\mathrm{HAp}$ nanoparticles. (C) Diffuse reflectance spectra of magnetite and the composite. (D) Scanning electron micrograph of $\mathrm{Fe}_{3} \mathrm{O}_{4}-\mathrm{HAp}$ nanoparticles.

Abbreviations: $\mathrm{Fe}_{3} \mathrm{O}_{4}$, iron oxide; $\mathrm{HAp}$, hydroxyapatite.

\section{Results and discussion}

\section{Fourier transform infrared spectroscopy}

The Fourier transform infrared spectral assignments for pure $\mathrm{Fe}_{3} \mathrm{O}_{4}, \mathrm{HAp}$, and the $\mathrm{Fe}_{3} \mathrm{O}_{4}$-HAp nanoparticles are shown in Figure 1B and tabulated in Table 1. From these data, the functional groups of prepared samples confirms the presence of pure $\mathrm{Fe}_{3} \mathrm{O}_{4}$ and pure $\mathrm{HAp}$. IN $\mathrm{Fe}_{3} \mathrm{O}_{4}$-HAp nanoparticles, a slight variation in spectral assignments confirms the close interaction between $\mathrm{Fe}_{3} \mathrm{O}_{4}$ and HAp.

\section{Diffuse reflectance spectroscopy}

Diffuse reflectance spectroscopy provides the electron transition of pure and mixed samples. Figure $1 \mathrm{C}$ represents the diffuse reflectance spectra for pure $\mathrm{Fe}_{3} \mathrm{O}_{4}$ and $\mathrm{Fe}_{3} \mathrm{O}_{4}-\mathrm{HAp}$. Pure $\mathrm{Fe}_{3} \mathrm{O}_{4}$ shows a wavelength $\left({ }^{4} \mathrm{~T}_{1}\right)$ transition in the range of 780-830 nm and an electron pair transition of $510 \mathrm{~nm}$. This shows a higher position of the ligand-to-metal charge transfer transition and pair transition band of red $\mathrm{Fe}_{3} \mathrm{O}_{4}$.

\section{Scanning electron microscopy}

The micromorphology and texture of the $\mathrm{Fe}_{3} \mathrm{O}_{4}$-HAp nanocomposites are shown in Figure 1D. This scanning electron microscopic image shows that pure $\mathrm{Fe}_{3} \mathrm{O}_{4}$ has an irregular approximately spherical-like morphology with an average particle size in the range of 50-70 $\mathrm{nm}$ and that HAp has a particle size in the range of $30-40 \mathrm{~nm}$. The aggregated $\mathrm{Fe}_{3} \mathrm{O}_{4}$-HAp clusters have a size range of 100-350 nm and both phases distributed uniformly, as shown in Figure 1D. The characteristic dark and light gray represents the $\mathrm{Fe}_{3} \mathrm{O}_{4}$ and HAp, respectively.

\section{Thermogravimetric analysis}

The $\mathrm{Fe}_{3} \mathrm{O}_{4}$-HAp nanoparticles were studied by thermogravimetric analysis in a nitrogen atmosphere at a heating rate of $20^{\circ} \mathrm{C}$ per minute. Figure 3 shows the thermogravimetric analysis curves, depicting the variations in residual mass of the samples with increasing temperature. The absolute weight loss from 


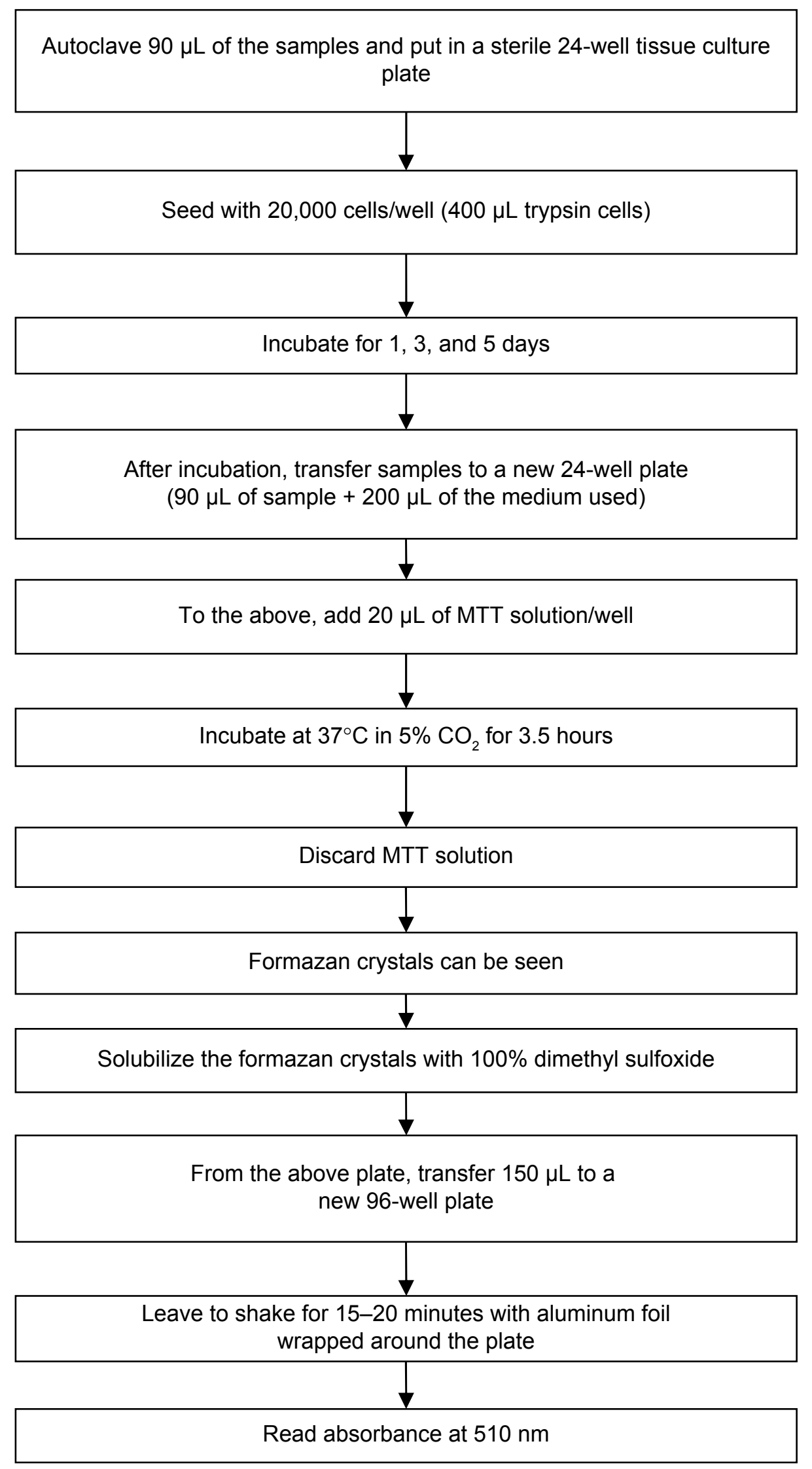

Figure 2 Flow chart showing the MTT assay procedure. 
Table I Fourier transform infrared spectral assignments of pure $\mathrm{Fe}_{3} \mathrm{O}_{4}, \mathrm{HAp}$, and $\mathrm{Fe}_{3} \mathrm{O}_{4}-\mathrm{HAp}$ nanoparticles

\begin{tabular}{|c|c|c|c|c|}
\hline \multirow[t]{2}{*}{ S No } & \multicolumn{3}{|c|}{ Wave number $\left(\mathrm{cm}^{-1}\right)$} & \multirow[t]{2}{*}{ Spectral assignments } \\
\hline & $\mathrm{Fe}_{3} \mathrm{O}_{4}$ & HAp & $\mathrm{Fe}_{3} \mathrm{O}_{4}$-HAp & \\
\hline I & - & 3,639 & 3,639 & $\mathrm{OH}^{-}$group, $\mathrm{CaO}$ \\
\hline 2 & - & 3,561 & 3,570 & Stretching mode of $\mathrm{OH}^{-}$group \\
\hline 3 & 3,420 & - & 3,420 & $\mathrm{H}_{2} \mathrm{O}, \mathrm{OH}^{-}$group \\
\hline 4 & - & 2,080 & - & Phosphate group $\left(\mathrm{PO}_{4}^{3-}\right)$ /absorbed $\mathrm{CO}_{3}{ }^{2-}$ \\
\hline 5 & - & 2,003 & - & Phosphate group $\left(\mathrm{PO}_{4}^{3-}\right) /$ absorbed $\mathrm{CO}_{3}{ }^{2-}$ \\
\hline 6 & - & - & 1,638 & $\mathrm{O}-\mathrm{H}$ in-plane bending \\
\hline 7 & 1,625 & - & - & $(\mathrm{H}-\mathrm{O}-\mathrm{H})$ adsorbed water \\
\hline 8 & - & 1,473 & 1,473 & $\mathrm{CO}_{3}^{2-}$ \\
\hline 9 & $\mathrm{I}, 383$ & - & - & $\mathrm{N}-\mathrm{O}$ nitro compounds \\
\hline 10 & $\mathrm{I}, \mathrm{I} \mid \mathrm{I}$ & - & - & $\mathrm{C}-\mathrm{O}$ \\
\hline II & - & - & $|, 09|$ & Phosphate group $\left(\mathrm{PO}_{4}^{3-}\right)$ \\
\hline 12 & 1,062 & - & - & $\mathrm{C}-\mathrm{O}$ \\
\hline 13 & - & 1,046 & 1,046 & Phosphate group $\left(\mathrm{PO}_{4}^{3-}\right)$ \\
\hline 14 & - & - & 960 & Phosphate group $\left(\mathrm{PO}_{4}^{3-}\right)$ \\
\hline 15 & 891 & - & - & $\mathrm{C}-\mathrm{H}$ \\
\hline 16 & - & - & 875 & $\mathrm{C}-\mathrm{H}$ \\
\hline 17 & 797 & - & - & $\mathrm{C}-\mathrm{H}$ \\
\hline 18 & - & - & 629 & $\mathrm{C}-\mathrm{Cl}$ \\
\hline 19 & - & - & 601 & O-P-O bending \\
\hline 20 & 588 & - & - & $\mathrm{Fe}-\mathrm{O}-\mathrm{Fe}$ bond ( $\mathrm{Fe}$ ions in tetrahedral and octahedral site) \\
\hline 21 & - & 566 & 566 & O-P-O bending \\
\hline
\end{tabular}

Abbreviations: $\mathrm{Fe}_{3} \mathrm{O}_{4}$, iron oxide; $\mathrm{HAp}$, hydroxyapatite.

the uncoated $\mathrm{Fe}_{3} \mathrm{O}_{4}$ is nearly $17 \%$ for the whole temperature range due to removal of adsorbed physical and chemical water. Another $5 \%$ weight loss was seen from $160^{\circ} \mathrm{C}$ to $300^{\circ} \mathrm{C}$, and this was associated with decomposition of residual chemical compounds. No significant weight loss was observed at higher temperatures. Thermogravimetric analysis of the $\mathrm{Fe}_{3} \mathrm{O}_{4}-\mathrm{HAp}$ powder showed weight loss up to a temperature of $800^{\circ} \mathrm{C}$ and thereafter weight remained constant.

The first stage of weight loss is between $90^{\circ} \mathrm{C}$ and $390^{\circ} \mathrm{C}$, which corresponds to dehydration of the precipitating complex and loss of physically adsorbed water molecules from the HAp powder. The weight loss in this region is $10 \%$.

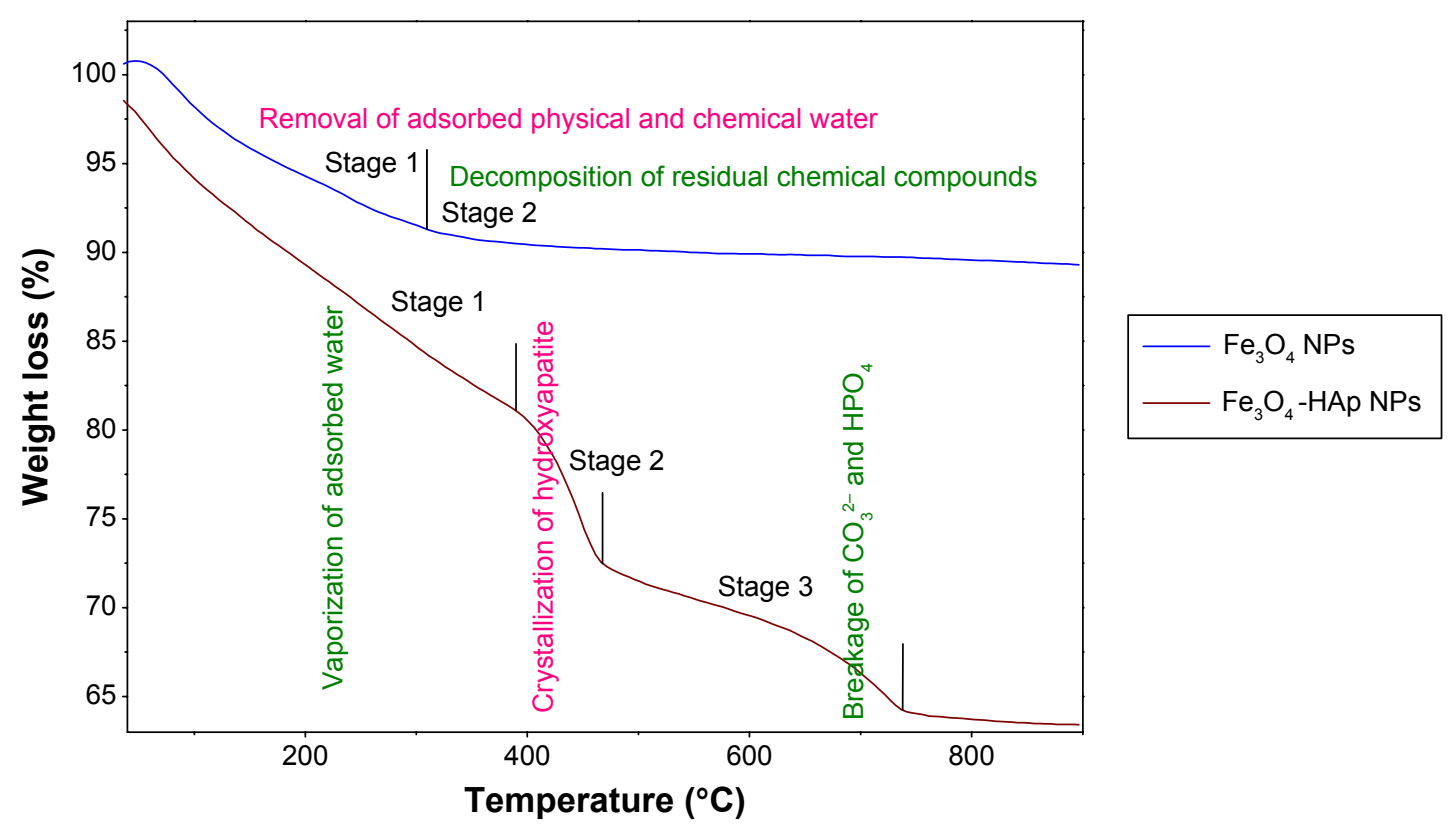

Figure 3 Weight loss from the $\mathrm{Fe}_{3} \mathrm{O}_{4}-\mathrm{HAp}$ nanoparticles.

Abbreviations: $\mathrm{Fe}_{3} \mathrm{O}_{4}$, iron oxide; HAp, hydroxyapatite; NPs, nanoparticles. 
Stage 1 corresponds to vaporization of adsorbed water on the surface of HAp, stage 2 is due to vaporization of the water and crystallization of HAp, and stage 3 is probably due to breakage of $\mathrm{CO}_{3}{ }^{2-}$ and $\mathrm{HPO}_{4}$ in $\mathrm{HAp}$.

\section{Differential scanning calorimetry}

The differential scanning calorimetry analysis of $\mathrm{Fe}_{3} \mathrm{O}_{4}$ and the nanocomposite is shown in Figure 4. The pure $\mathrm{Fe}_{3} \mathrm{O}_{4}$ shows a strong endothermic peak approximately $100^{\circ} \mathrm{C}$. This is due to removal of the solvent molecule $\left(\mathrm{H}_{2} \mathrm{O}\right)$. A slight endothermic transition approximately $620^{\circ} \mathrm{C}$ indicates crystallization of the magnetite phase. The differential scanning calorimetry results for the $\mathrm{Fe}_{3} \mathrm{O}_{4}$-HAp nanocomposite show a strong endothermic peak located in the range of $90^{\circ} \mathrm{C}-110^{\circ} \mathrm{C}$. Two exothermic peaks were identified at $470^{\circ} \mathrm{C}$ and $720^{\circ} \mathrm{C}$. The first one could be due to crystallization of the powder, given that this temperature range allows strong interaction between $\mathrm{Fe}_{3} \mathrm{O}_{4}$ and $\mathrm{HAp}$ molecules. The second one corresponds to the rearrangement of the $\mathrm{CO}_{3}{ }^{2-}$ and $\mathrm{HPO}_{4}{ }^{-}$groups present in HAp. This is in good agreement with the thermogravimetric analysis.

\section{Vibrating sample magnetometry}

The magnetic hysteresis loops for the $\mathrm{Fe}_{3} \mathrm{O}_{4}$ nanoparticles and the $\mathrm{Fe}_{3} \mathrm{O}_{4}$-HAp nanocomposites is shown in Figure 5. These materials exhibited strong magnetic behavior, with saturation magnetization of 20.639 and $7.34 \mathrm{emu} / \mathrm{g}$ and coercivity of 4.1747 and $5.1233 \mathrm{G}$, respectively, at $300 \mathrm{~K}$. The magnetic properties are tabulated in Table 2. The saturation magnetization of pure $\mathrm{Fe}_{3} \mathrm{O}_{4}$ is lower than the value reported in the literature $(92 \mathrm{emu} / \mathrm{g}) .{ }^{13}$ The samples show typical superparamagnetic behavior, with near zero coercivity and remanent magnetization, whereas pure HAp does not have any hysteresis loop. It is also clear from vibrating sample magnetometry that the magnetite particle in the composite structure is well within the single domain particle range and exhibits superparamagnetism. The magnetization value of the composites was lower than that of the pure $\mathrm{Fe}_{3} \mathrm{O}_{4}$ nanoparticles. The decreased saturation magnetization could be due to interaction between the iron core and the HAp shell, which decreases the magnetic moment. ${ }^{14,15}$

\section{Cytotoxicity testing}

In vitro cytotoxicity assays are the primary biocompatibility screening tests for a wide variety of materials used in the medical field. The MTT assay was done for the $\mathrm{Fe}_{3} \mathrm{O}_{4}$ and $\mathrm{Fe}_{3} \mathrm{O}_{4}$-HAp nanoparticles using MG63 (osteosarcoma) cells. Three concentrations $(1,3$, and $5 \mathrm{mg} / \mathrm{mL})$ of the $\mathrm{Fe}_{3} \mathrm{O}_{4}$ nanoparticles and the $\mathrm{Fe}_{3} \mathrm{O}_{4}$-HAp nanocomposites were tested. The experiments were performed in triplicate. The mean values obtained are shown in Figure 6. The MTT assay procedure is explained in the flow chart given in Figure 2. The results show that the $\mathrm{Fe}_{3} \mathrm{O}_{4}$-HAp nanoparticles enabled better cell proliferation than the pure $\mathrm{Fe}_{3} \mathrm{O}_{4}$ at the concentrations tested.

Magnetic induction hyperthermia is a technique that can be used to destroy cancer cells via their hysteresis loss

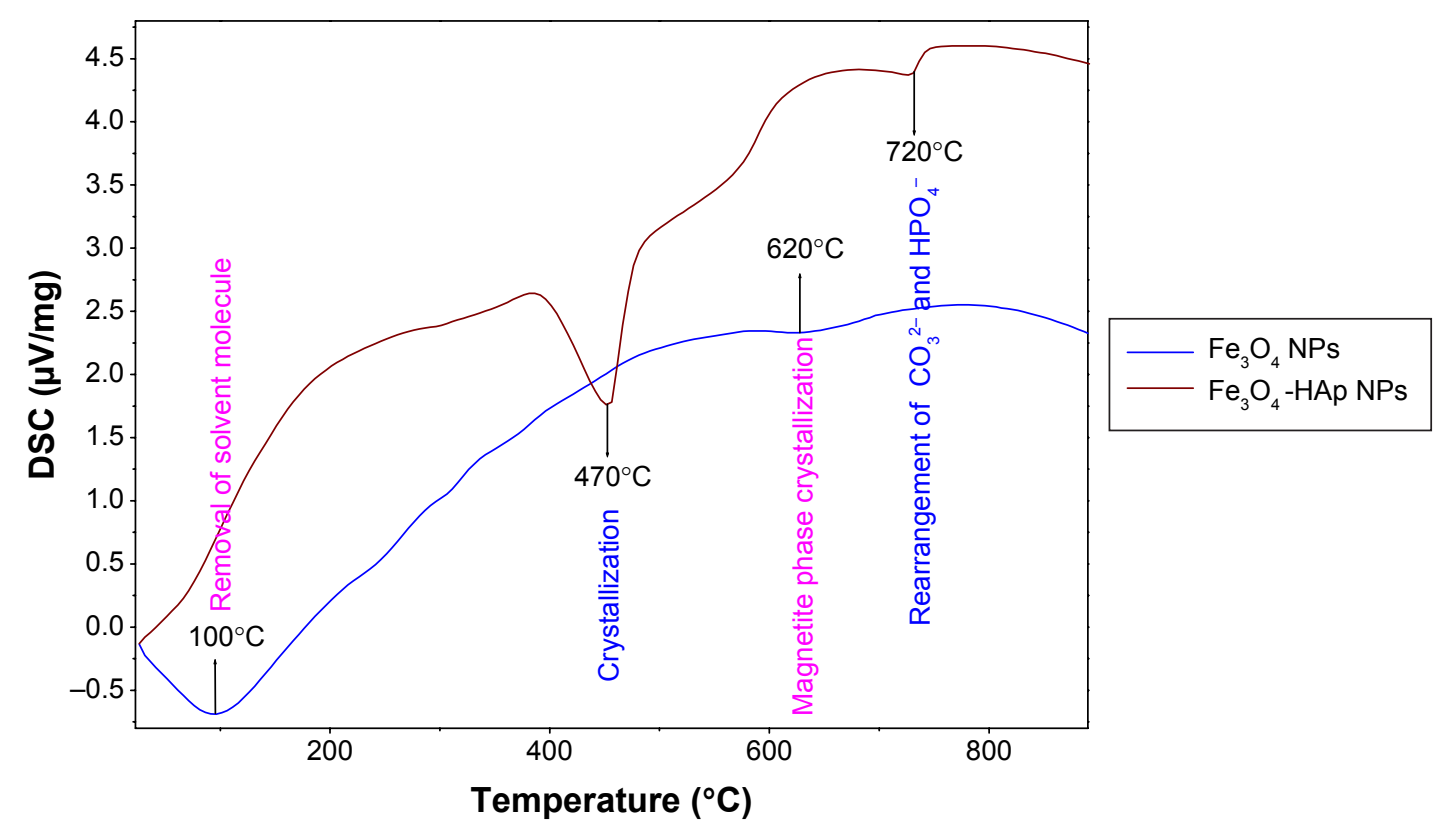

Figure 4 DSC analysis of $\mathrm{Fe}_{3} \mathrm{O}_{4}-\mathrm{HAp}$ nanoparticles.

Abbreviations: DSC, differential scanning calorimetry; $\mathrm{Fe}_{3} \mathrm{O}_{4}$, iron oxide; HAp, hydroxyapatite; NPs, nanoparticles. 


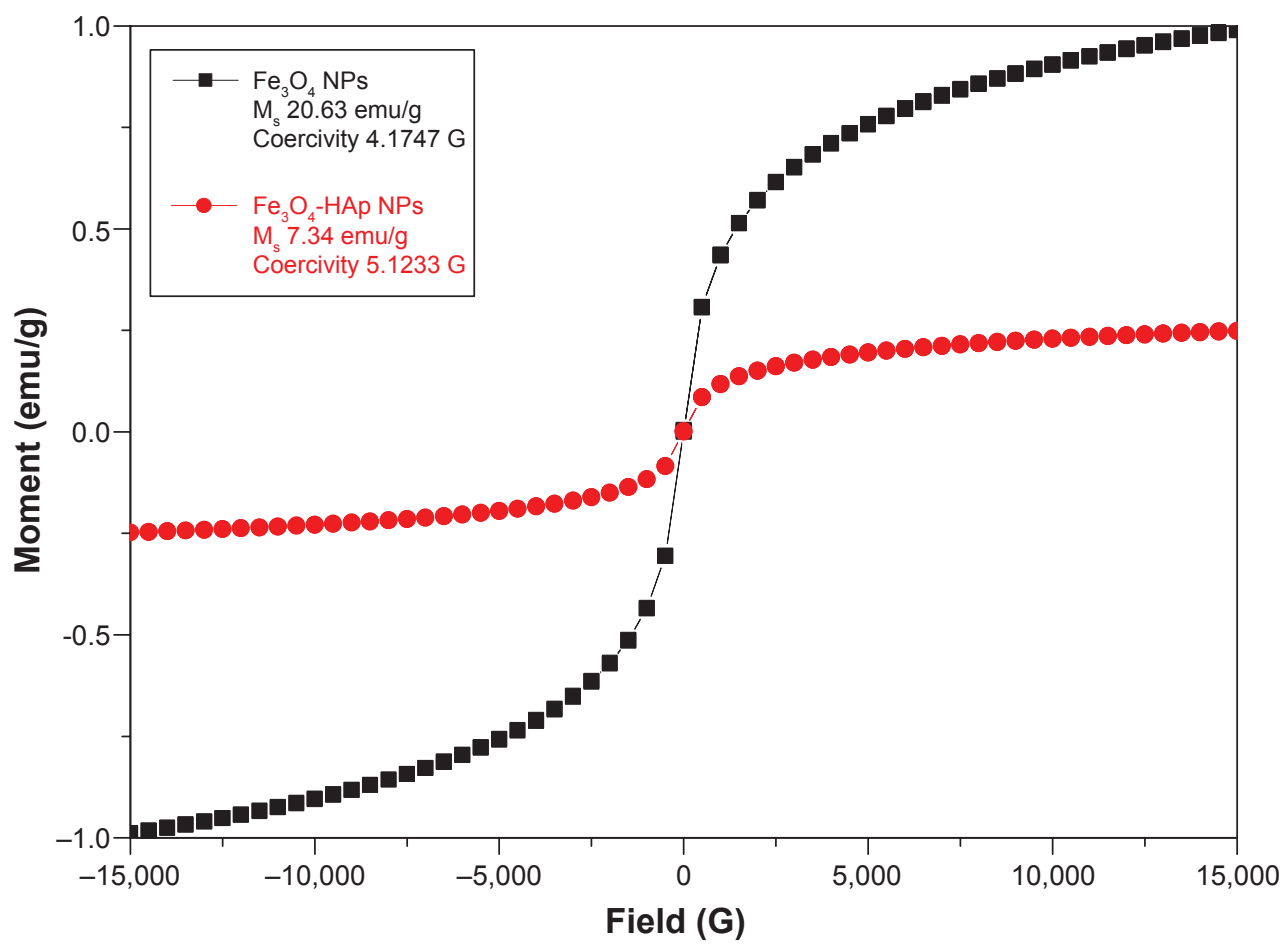

Figure 5 Magnetic hysteresis loops of pure $\mathrm{Fe}_{3} \mathrm{O}_{4}$ and $\mathrm{Fe}_{3} \mathrm{O}_{4}$ - $\mathrm{HAp}$ nanoparticles.

Abbreviations: $\mathrm{Fe}_{3} \mathrm{O}_{4}$, iron oxide; $\mathrm{HAp}$, hydroxyapatite; NPs, nanoparticles; $\mathrm{M}_{\mathrm{s}}$, saturation magnetization.

Table 2 Magnetic properties of $\mathrm{Fe}_{3} \mathrm{O}_{4}$ and $\mathrm{Fe}_{3} \mathrm{O}_{4}-\mathrm{HAp}$ nanoparticles

\begin{tabular}{llll}
\hline Sample & Coercivity (G) & Saturation magnetization (emu/g) & Remanent magnetization (G) \\
\hline $\mathrm{Fe}_{3} \mathrm{O}_{4}$ nanoparticle & 4.1747 & 20.639 & 0 \\
$\mathrm{Fe}_{3} \mathrm{O}_{4}$ - $\mathrm{HAp}$ nanocomposite & 5.1233 & 7.34 & 0 \\
\hline
\end{tabular}

Abbreviations: $\mathrm{Fe}_{3} \mathrm{O}_{4}$, iron oxide; $\mathrm{HAp}$, hydroxyapatite.

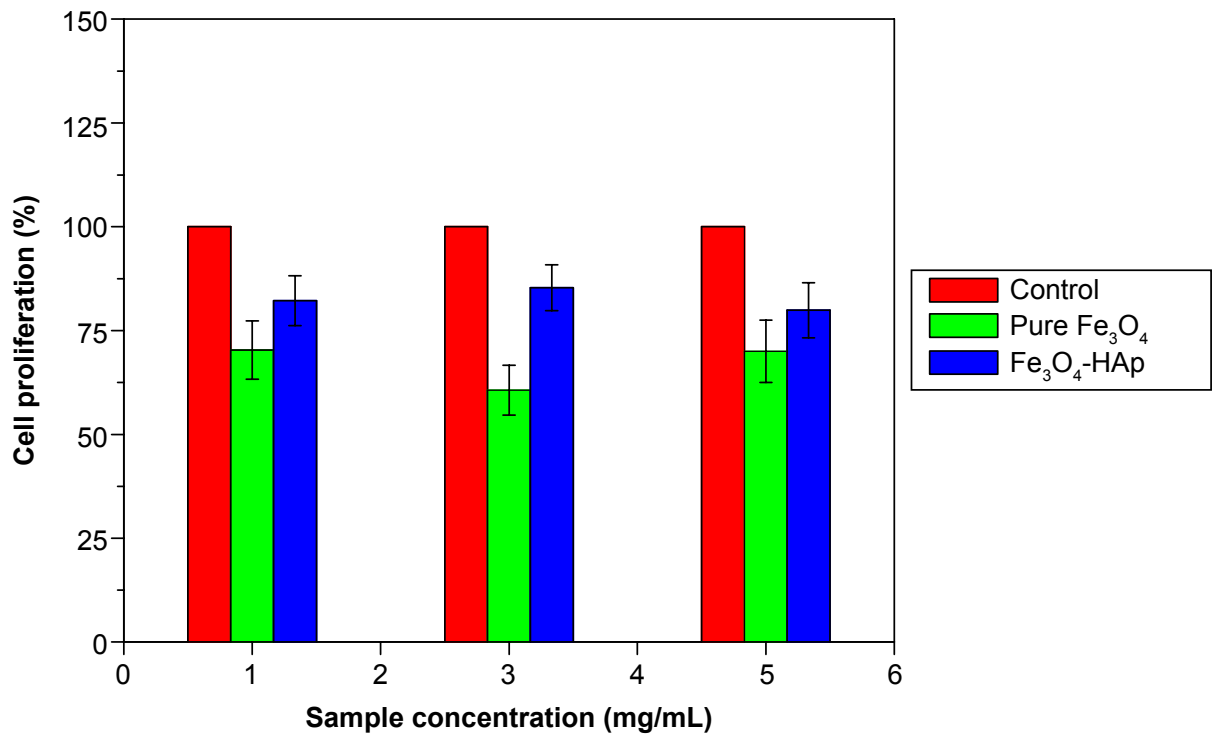

Figure 6 Cytotoxicity test for pure $\mathrm{Fe}_{3} \mathrm{O}_{4}$ and $\mathrm{Fe}_{3} \mathrm{O}_{4}-\mathrm{HAp}$ nanoparticles.

Abbreviations: $\mathrm{Fe}_{3} \mathrm{O}_{4}$, iron oxide; $\mathrm{HAp}$, hydroxyapatite. 
when placed in an alternating magnetic field. The prepared nanocomposites have the capacity to generate heat in the presence of an alternating magnetic field. The temperature of the cancer cells is raised between $42^{\circ} \mathrm{C}$ and $46^{\circ} \mathrm{C}$ via the heat produced by our prepared composite materials. Although the heating efficiency of the prepared superparamagnetic $\mathrm{Fe}_{3} \mathrm{O}_{4}$-HAp nanocomposite is not demonstrated here, Hou et $\mathrm{al}^{16}$ showed that a similar $\mathrm{Fe}_{3} \mathrm{O}_{4}$-HAp nanocomposite was capable of magnetically inducing effective thermal destruction of cancer cells in vivo.

\section{Conclusion}

In this work, pure $\mathrm{Fe}_{3} \mathrm{O}_{4}$ was prepared by alkaline coprecipitation and HAp nanoparticles were prepared using an optimized sol-gel method. $\mathrm{Fe}_{3} \mathrm{O}_{4}$-HAp $(0.7 \mathrm{w} / \mathrm{w})$ nanocomposites were developed by wet milling. The prepared $\mathrm{Fe}_{3} \mathrm{O}_{4}{ }^{-}$ HAp nanoparticles and its composite were characterized and confirmed by scanning electron microscopy, Fourier transform infrared spectroscopy, and diffuse reflectance spectroscopy. Their superparamagnetic nature was confirmed by vibrating sample magnetometry, and their thermal stability was confirmed by thermogravimetric analysis and differential scanning calorimetry. This nanostructured $\mathrm{Fe}_{3} \mathrm{O}_{4}$-HAp composite would be ideal for use in bone cancer therapy.

\section{Acknowledgments}

The authors are grateful to their head of department, dean, principal, and management for providing the facilities to carry out this research. MS is grateful to TEQIP-II for providing a $\mathrm{PhD}$ research assistantship. This work was financially supported by DST (SB/S2/CMP-106/2013), New Delhi, and UGC (major, 42-907/2013SR), New Delhi.

\section{Disclosure}

The authors report no conflicts of interest in this work.

\section{References}

1. Jiang QL, Zheng SW, Hong RY, et al. Folic acid conjugated $\mathrm{Fe}_{3} \mathrm{O}_{4}$ magnetic nanoparticles for hyperthermia and MRI in vitro and in vivo. Appl Surf Sci. 2014;307:224-233.

2. Di Corato R, Espinosa A, Lartigue L, et al. Magnetic hyperthermia efficiency in the cellular environment for different nanoparticle designs. Biomaterials. 2014;35:6400-6411.

3. Pankhurst QA, Connolly J, Jones SK, Dobson J. Applications of magnetic nanoparticles in biomedicine. J Phys D Appl Phys. 2003;36: R167-R181.

4. Bear JC, Yu B, Blanco-Andujar C, et al. A low cost synthesis method for functionalised iron oxide nanoparticles for magnetic hyperthermia from readily available materials. Faraday Discuss. 2014;175:83-95.

5. Bonnemain B. Superparamagnetic agents in magnetic resonance imaging: physicochemical characteristics and clinical applications - a review. J Drug Target. 1998;6:167-174.

6. Singh RK, El-Fiqi AM, Patel KD, Kim HW. A novel preparation of magnetic hydroxyapatite nanotubes. Mater Lett. 2012;75:130-133.

7. Karunamoorthi R, Kumar GS, Prasad AI, Vatsa RK, Thamizhavel A, Girija EK. Fabrication of a novel biocompatible magnetic biomaterial with hyperthermia potential. J Am Ceram Soc. 2014;97:1115-1122.

8. Murakami S, Hosono T, Jeyadevan B, Kamitakahara M, Ioku K. Hydrothermal synthesis of magnetite/hydroxyapatite composite material for hyperthermia therapy for bone cancer. J Am Ceram Soc. 2008; 116:950-954.

9. Iwasaki T, Nakatsuka R, Murase K, Takata H, Nakamura H, Watano S. Simple and rapid synthesis of magnetite/hydroxyapatite composites for hyperthermia treatments via a mechanochemical route. Int $J \mathrm{Mol}$ Sci. 2013;14:9365-9378.

10. Donadel K, Felisberto MD, Laranjeira MC. Preparation and characterization of hydroxyapatite-coated iron oxide particles by spray-drying technique. An Acad Bras Cienc. 2009;81:179-186.

11. Tampieri A, D'Alessandro T, Sandri M, et al. Intrinsic magnetism and hyperthermia in bioactive Fe-doped hydroxyapatite. Acta Biomater. 2012;8:843-851.

12. Gupta AK, Gupta M. Synthesis and surface engineering of iron oxide nanoparticles for biomedical applications. Biomaterials. 2005;26: 3995-4021.

13. Bretcanu O, Spriano S, Brovarone C, Verne E. Synthesis and characterization of coprecipitation-derived ferromagnetic glass-ceramic. J Mater Sci. 2006;41:1029-1037.

14. Cheng J, Ni X, Zheng H, Li B, Zhang X, Zhan D. Preparation of Fe (core) $/ \mathrm{SiO}_{2}$ (shell) composite particles with improved oxidation resistance. Mater Res Bull. 2006;41:1424-1429.

15. Ramanujan RV, Yeow YY. Synthesis and characterization of polymercoated metallic magnetic materials. Mater Sci Eng C. 2005;25:39-41.

16. Hou CH, Hou SM, Hsueh YS, Lin J, Wu HC, Lin FH. The in vivo performance of biomagnetic hydroxyapatite nanoparticles in cancer hyperthermia therapy. Biomaterials. 2009;30:3956-3960.
International Journal of Nanomedicine

\section{Publish your work in this journal}

The International Journal of Nanomedicine is an international, peerreviewed journal focusing on the application of nanotechnology in diagnostics, therapeutics, and drug delivery systems throughout the biomedical field. This journal is indexed on PubMed Central, MedLine, CAS, SciSearch ${ }^{\circledR}$, Current Contents ${ }^{\circledR} /$ Clinical Medicine,

\section{Dovepress}

Journal Citation Reports/Science Edition, EMBase, Scopus and the Elsevier Bibliographic databases. The manuscript management system is completely online and includes a very quick and fair peer-review system, which is all easy to use. Visit http://www.dovepress.com/ testimonials.php to read real quotes from published authors. 